UDC 336.02:331 (477)

JEL Classification: O55, E24, G19, E62, E52, C34

http://doi.org/10.21272/mmi.2018.4-09

Ibrahim Hassan Bakari,

Ph.D., Associate Professor, Modibbo Adama University of Technology, Nigeria

Adamu Idi,

Assistant Lecturer, Gombe State University, Nigeria

Yusrah Ibrahim,

Gombe State University, Nigeria

\title{
INNOVATION DETERMINANTS OF FINANCIAL INCLUSION IN TOP TEN AFRICAN COUNTRIES: A SYSTEM GMM APPROACH
}

Abstract. Financial inclusion has been acclaimed to play a significant role in combating the three evils of poverty, unemployment and poverty, which have been a serious hindrance to the growth path of developing countries like Africa. It was against this that, this paper examined the drivers of financial inclusion in the top ten African economies in terms of gross domestic product growth rate. These include Angola, Algeria, Egypt, Kenya, Libya, Nigeria, Morocco, South Africa, Sudan and Tunisia. Covering a period of 2000 to 2015, using System generalized method of moment, which is considered superior to other panel data models due to its ability to address the problem of omission bias, endogeneity and autocorrelation. The data were obtained from World Development Indicators and Worldwide Governance Indicators which are being considered the most efficient sources of data, especially in developing countries. The study reveal that mobile banking, bank branches, political stability, interest rate, and inflation positively drive financial inclusion while income, access to Automated Teller Machine, and government expenditure have the negative impact on financial inclusion. On the bases of the above findings, it was concluded that mobile banking, bank branches, political stability, interest and inflation rate are the major determinants of financial inclusion in Africa. Based on the conclusion, the study recommends that appropriate financial sector policies and measures should be designed by the stakeholders in the financial system in form of low monetary policy rate to encourage access to financial services by all segment of the society. In addition to strict legislation, the can stop banks exploiting their customers through unnecessary bank charges and ensure the penetration of financial institutions into the rural areas. Fiscal and monetary policies should target an increase in the welfare of the masses especially the low-income earners in the society who are mostly excluded in Africa.

Keywords: Africa, employment, financial inclusion, fiscal policy, monetary policy, system GMM.

Introduction. Africa is the second fastest growing economy behind Asia, with over 5 per cent gross domestic product (GDP) growth rate over a decade. Despite the rapid economic growth in the continent, the growing prosperity has not been translated into to the welfare of the masses as evidence in the high rate of unemployment, poverty, and inequality (Triki \& Faye, 2013).

However, for growth to be sustainable, it has to be politically, economically and socially inclusive, and one of the cardinal areas of inclusive growth is financial inclusion in which it has fallen behind other regions in the globe. Only 23 per cent of the African adult population has access to the formal account, which is far below the global average of 50 per cent, relative to 92 per cent in advanced economies, 43 per cent in Asia and 35 per cent in Latin America. Within the African sub-region, Southern African countries have 42 per cent, 23 per cent in West Africa, 22 per cent in East Africa, 20 per cent in North Africa and 7 per cent in Central Africa (World Bank, 2014).

In its basic term, financial inclusion refers to all measures and strategies put in place to ensure the availability of the formal financial product at an affordable cost to all segment of the society (Triki \& Faye, 2012). This simply means given attention to a particular group of people that have been financially excluded from a formal financial system basically due to either their level of income, gender, level of education, geographical location, lack of physical access, religion, or documentation requirement.

Cite as: Bakari, I. H., Idi, A., \& Ibrahim, Y. (2018). Innovation Determinants of Financial Inclusion in Top Ten African Countries: a System GMM Approach. Marketing and Management of Innovations, 4, 98-106. http://doi.org/10.21272/mmi.2018.4-09 
Studies have established a link between financial inclusion and poverty reduction, and economic growth (see Evans \& Adeoye, 2016 and Kim, Yu \& Hassan, 2018). Hence, to achieve an inclusive growth that is capable of increasing employment opportunities, reducing poverty, and increase the welfare of the masses in general, various policies and programs have been launched these include, the Maya Declaration, the Global agenda for Financial Inclusion action plan, aim at universal access to basic financial services. To achieve this goal, The World Bank Development Research (2014) constructed an index of financial inclusion, that capture some indicators of financial inclusion to know the magnitude of financial exclusion so as to design appropriate measures to address the problem, at national level many countries have embarked on financial sector reforms, and other strategies to enhance the level of financial inclusion especially in Africa which has fallen behind other continents in the globe.

In designing appropriate policies and strategies to promote financial inclusion, what determine access to financial services have to be identified as this will policymakers. It is against this background that these study sick to examine the determinants of financial inclusion in Africa to contribute to the existing literature on financial inclusion and to help policymakers and stakeholders in designing appropriate policies that will promote financial inclusion in the region.

Conceptual Issues. The Concept of Financial Inclusion. Financial inclusion is considered one of the strategic means of financial development (Beck et, al 2015). This is because financial development is the means through which households and firms meet their financial obligations at an affordable cost (Francis, 2017). Financial inclusion comprises access to usage, quality, and impact of such inclusion effort on economic growth and developments (Hannig \& Jansen, 2010; Triki \& Faye 2013).

According to the Reserve bank of India, (2008) financial inclusion is a process of ensuring access to appropriate financial products and services needed by vulnerable groups such as the weaker sections and low-income groups at an affordable cost in a fair and transparent manner by mainstream institutional players. Central Bank of Nigeria (2012) define financial inclusion as a situation when adults have easy access to a broad range of financial product designed according to their needs and provided at affordable costs. These products include payments, savings, credits, insurance and pension.

The Asymmetric Information Theory of Financial Inclusion. This model is based on the assumption that financial exclusion is largely associated with imperfect information about the existing formal financial products in the financial market, which can be addressed with the improvement in the information and communication technology across all sections of the society at an affordable cost. Asymmetric information inform of moral hazard and adverse selection can affect the individual likelihood to access financial services through doubt, lack of trust and confidence in the available products (Rajasekaran, 2018). Asymmetric information is said to exist when one party in a transaction is said to have more information on the product that the other party or a situation where one party in a transaction cannot observe the action of the other in the market (Varian, 2010). The persistence of this problem can cause both supply and demand of financial products to be affected negatively, the suppliers of the products may lose confidence on the consumers if they cannot observe the complete action or if they realize that their clients have more information about their ability to meet the full obligation through past experience. Similarly, the consumers demand financial services may also be affected if they think that financial institutions have more information on the product that is not favourable to them. This most a time can make potential customers or borrowers and financial services providers to have the wrong perception about each other. this will each party involve in the transaction to be extra careful in their operations in the market which will affect the rate of access to the product by the individuals who could have access those products without such measures taken.

The problem of asymmetric information is more prevalent in the developing countries especially rural areas where financial services providers find it difficult to address despite the low rate of financial inclusion. People tend to have more priority on the informal sources of financial resources largely due to the facts 
that the informal financial product providers can easily correct informal barriers caused by imperfect information. This is achieved through the provision of informal financial product at a low or zero cost of information in addition to easy access to the product offered by the informal lenders.

Perfect information plays a vital role in the financial system, this is because most of the financial transaction-taking place in the financial market is forward in nature. This has warranted the need to know the identity, and the intention of the user of the financial product providers and users to serve as a yardstick to evaluate the parties in the transactions' ability to meet the obligation. Financial services providers will be affected if the information pertaining to the buyers or users of financial products is wrong or fail to meet the legal requirement provided by the services providers. This regulations and requirements will affect access and use of financial services. To address this problem, the apex regulatory agencies like central banks and other stakeholders in the financial system can come up with measures that will motivate people to have access to formal financial services.

Empirical Review. Adeyemi, Pramanik \& Meera (2012), investigated the determinants of financial among Muslims in llorin, using structural equation model reported that, being eligible to open an account is the significant factor in financial inclusion. The study also reveals that affordability and availability of the services is the significant factor in Nigeria that about 50 per cent of the financially excluded persons is due to lack of affordability and access to the services. Sharma \& Kukreja (2013), investigated the relevance of financial inclusion in developing countries, using descriptive statistical tools, reported that strengthening credits channels and address the formidable challenges of financial inclusion in developing countries, and hence bridge the gap in financial inclusion. Zuzana \& Weill (2014), investigated the understanding of financial inclusion in China using a binary logit model, reported, that a high level of financial inclusion in China compare to other BRICS countries is associated with greater use of formal accounts due to high level of employment, income, availability of the financial products and mobile banking facilities. The study further reveals that financial exclusion is a voluntary rather than involuntary in China. However, in the case of access to credits, people prefer to borrow from friends and relatives than formal financial institution due to the cost of services. Bapat \& Biswa (2016) investigated the determinants of financial inclusion among Indian urban poor, using logistic regression, reported that expenditure, level of income, savings and lending behaviour of financial institutions have a significant impact on financial inclusion.

Soumare, Tchana \& Kengne (2016), investigated the determinants of financial inclusion in West and Central Africa using logistic regression model, reported that, ability and desire to save and borrow in a formal financial institution affect individual's access to formal financial products. The study also reveals that high-income people tend to have more access to financial services because of their desire to save than low-income earners who spend a significant part of their income on consumption.

Zins \& Weill (2016), investigated the determinants of financial inclusion in Africa, using probit model, reported that, mobile money facilities, access to internet, motivation for savings and loan, motivation for farming business, to save for old age, medical expenses, payments of school fees, purchase of land for business and building of a house are significant determinants of financial inclusion especially in developing countries.

Fawowe (2017), investigated access to financial services and firms performance in Africa, using fixed and random effects model, reported that creditworthiness influence the decision to open an account and borrow to carry out daily activities. The study also reveals that countries with low credit constraints tend to have a high rate of financial inclusion relative to the once with strict requirements. Iqbal \& Sami (2017), investigated the role of a bank in financial inclusion in India, reported that availability of Automated Teller Machine (ATM), Point of Sales device (POS), and credit and debit card determined access to financial services. the study also reveals that Indian financial inclusion success is related to the spread of financial institutions across both urban and rural areas and ATMs that significantly influence ownership of formal bank accounts. 
Kuri \& Laha (2017), investigated the determinants of financial inclusion in West Bengal, using binary probit model reported that the increase in the asset of households and the desire for savings influence access to financial services. the study also reports that financial literacy through awareness in schools, media and national dailies on the basic financial product such as owning accounts, saving and credits is a significant determinant of financial inclusion. Ouma, Odongo \& Were (2017), investigated the use of mobile financial services and financial inclusion, and whether it is a boom for savings mobilization, using logistic regression reported that availability and use of mobile phone have significant impacts on access to financial services. the study also reveals that mobile financial service influence the amount to save and due the convenience attached to mobile banking, it can promote access to banking services and greater financial inclusion.

Rao \& Baza (2017), investigated the barriers to financial inclusion and use of financial services in Ethiopia, reported that access to physical points of financial services, poverty, lack of motivation, the exorbitant cost of the transaction, legal and regulatory requirement to open accounts have the influence on financial. Sahoo, Pradhan \& Sahu (2017), investigated the determinants of financial inclusion in the tribal district of Odisha, using logistic regression, reported that size of privately own land which serves collateral to obtain a loan in the formal financial services, total annual income, and availability of employment generation scheme has a positive impact on financial inclusion. The study also reveals that people that engage in employment generation scheme have more likelihood having access to formal financial services.

Singh, Sikdar \& Chaturvedi (2017), investigated the determinants of financial inclusion in India, using logistic regression, reported that documentation requirements, income level, proximity to financial services providers, are significant determinants of access to financial services. the study also reveals that highincome earners are more likely to have access to financial services and that strict documentation requirements are among has negative effects on access to formal financial services. Abel, Mustandwa \& Le Roux (2018), review the determinants of financial inclusion and reported that household level of income and access to internet facilities have a significant impact on financial inclusion. The study also reveals that higher income earners that can afford internet facilities have more likelihood to access financial product. That documentation requirement has a negative impact on financial inclusion.

Allen, Demirguc-Kunt, Klapper \& Peria (2018), study the foundation of financial inclusion and understand ownership and use of formal account, using multiple regression, reported that, level of income, level of confidence on financial service providers, cost of direct credits, ATM penetration, and consumer protection are significant determinants and solid foundation of financial inclusion. The study further reveals that removing documentation requirements and cost of opening account play a significant role in financial inclusion. Rajasekaran (2018), study how to include the excluded and the scenario of financial inclusion in India, reported that proximity to the financial product, regular and stable income, low cost of financial services, and lack of strict documentation requirements can include the excluded into the formal financial services. The study further reveals that the creation of employment opportunities and financial inclusion policies and strategies are the best scenario for financial inclusion.

This study will contribute to the literature by examining the determinants of financial inclusion in top ten African countries, as it will help in designing policies and strategies of financial inclusion in the continent and other places having the same characteristics.

Sources of Data. The study employs time series data, specifically panel data covering the period of 2000 to 2015, in African countries, which was obtained from World Development Indicators (2017) and World Governance indicators (2017). The source of the data was considered efficient because given the scope of the study that is wide it provides a more reliable data at macro level than other sources (Evans and Adeoye, 2016). To examine the drivers of financial inclusion in the top ten African Countries. The structural form of the model can be specified as follows: 


$$
\begin{gathered}
\text { Fin }=F(\text { Income }, \text { ATMAccess, } \text { MobileBanking, CBranches, } \text { PoliticalStability, } \\
\text { InterestRate, } \text { Inflation, Govexp })
\end{gathered}
$$

Fin is financial inclusion proxied by the financial inclusion index constructed from accounts ownership, per 1000, savings and credit to the private sector as a percentage of GDP where principal component analysis. While income is the per capita income, ATMAccess is Automated Teller Machine per 100,000 people, MobileBanking is access to internet banking per 1000 people, CBranches is commercial bank branches, political stability is a measure of the degree of stability, interest rate is the deposit interest rate, inflation is the consumer price index and Govexp is total government expenditure.

The econometrics form of the model is specified as:

$$
\operatorname{Fin}_{i t}=\Omega_{i}+\beta_{i} \sum_{j=1}^{p} X_{i t}+\lambda_{i t}
$$

where $\Omega$ is the constant intercept, $\beta$ is the slop parameters to be estimated, $X$ is the vector of independent variables, $\lambda$ is the composite error term, $j$ is the individual country and $t$ is time.

Given that, many economic variables are dynamic in nature and to adequately capture the dynamic process, the study employs a dynamic panel model. Unlike the static panel, dynamic panel help the researcher to capture the dynamic effect by capturing the effect of shocks on the dependent variable, autocorrelation and endogeneity (Henderson and Hsiao, 1981, and Arellano and Bond, 1991).

The dynamic panel data model is specified below:

$$
Y_{i t}=\Omega_{i}+Y_{i t-1}+\beta_{i} \sum_{j=1}^{p} X_{i t}+\lambda_{i t}
$$

where $Y_{i t-1}$ is the lagged dependent, which captures the dynamic effect.

With the introduction of lagged dependent on the model, the model is now prone to the problem of autocorrelation and endogeneity, which affect the efficiency of the results. This has led to the development of the Generalized Method of Moment (GMM), which suggested the use of instruments in trying to address the problem. The GMM is decomposed into the difference GMM developed by Henderson and Hsiao (1981) and Arellano and Bond (1991) that suggest differencing the model and using the lagged values of the lagged dependence as the instrument to address both autocorrelation and endogeneity problems.

$$
\Delta Y_{i t}=\Omega_{i}+\Delta Y_{i t-1}+\beta_{i} \sum_{j=1}^{p} \Delta X_{i t}+\Delta \lambda_{i t}
$$

where $\Delta$ is the change.

Contrary to this, position Arellano and Bover (1995), and Blundell, and Bond (1998) assert that by differencing the model, it will cause the problem of the small sample and omission variable bias and inconsistency in the result. This has led to the development of system GMM. The advantage of system GMM over Difference GMM is that it takes into account the values of lagged dependence and explanatory variables as instruments to attained a robust and consistent result. The robustness of the instrument used in the model will be checked using the Arellano and Bond (1991) specification test of overidentifying restriction known as the Sargan test use to test the validity of the instrument and the AR test for absent of first-order autocorrelation test.

The principal component analysis was employed to construct a financial inclusion index. Principal 
component analysis is the statistical method that employs an orthogonal transformation to convert some set of observations that are possibly correlated into an uncorrelated linear variable known as principal components. The principal component can be less than or equal to the original number of variables and the conversion is done in such a way that the first component has the highest value of possible variance, and in addition, the subsequent component also have high variance base on the constraint assumption of they are orthogonal to the previous component. In constructing the index, three variables account ownership per 1000 , savings, and credit to the private sector were use to construct a single index of financial inclusion. The formula for computing the index is given as:

$$
F j=W j_{1} X_{1}+W j_{2} X_{2}+W j_{3} X_{3}
$$

where $f j$ is the estimate of the $j$ th factor, $W_{j}$ is the weight on the factor scores coefficient and $\mathrm{Xj}$ is the variable

Data estimation and Analysis. Table 1 present the result of both difference and system GMM, the analysis is based on the result of system GMM that is assumed to more efficient.

Table 1 - Dynamic panel results

\begin{tabular}{|c|c|c|}
\hline Variable & Difference GMM & System GMM \\
\hline \multirow{2}{*}{ Lagged FIN } & 0.388 & 0.796 \\
& $(0.115)^{\star * *}$ & $(0.107)^{\star * *}$ \\
\hline \multirow{2}{*}{ NNCOME } & -3.740 & -1.070 \\
& $(2.430)$ & $(1.740)$ \\
\hline \multirow{2}{*}{ ATMACCESS } & -0.006 & -0.002 \\
& $(0.014)$ & $(0.178)$ \\
\hline \multirow{2}{*}{ MOBILEBANKING } & -3.980 & 3.780 \\
& $(6.290)$ & $(6.750)$ \\
\hline \multirow{2}{*}{ CBRANCHES } & 0.819 & 0.719 \\
& $(0.077)$ & $(0.577)$ \\
\hline \multirow{2}{*}{ POLITICALSTABILITY } & -0.008 & 0.011 \\
& $(0.006)$ & $(0.006)^{*}$ \\
\hline \multirow{2}{*}{ INTEREST RATE } & 0.002 & 0.023 \\
& $(0.007)$ & $(0.009)^{*}$ \\
\hline \multirow{2}{*}{ INFLATION } & -0.002 & 0.004 \\
& $(0.012)$ & $(0.183)$ \\
\hline \multirow{2}{*}{ GOVEXP } & -0.056 & -0.015 \\
& $(0.009)$ & $(0.103)$ \\
\hline N & 47 & 55 \\
\hline Wald ${ }^{2}$ & $101.98^{* * *}$ & $399.36^{* * *}$ \\
\hline Sargan & 43.016 & 41.153 \\
\hline
\end{tabular}

Note: The $\left(^{* *}\right),\left(^{*}\right)$ Signifies variable significant at $1 \%$ and $10 \%$ respectively. Standard errors in parenthesis.

Source: Author's computation using Stata 14.

The coefficient of the lagged dependent variable is positive and statistically significant. It is important because it shows a contemporaneous or catches up effect, a zero value indicates full catch and the range 
between zero and one indicate partial catch up depending on the value. In our model, the coefficient of the lagged value of financial inclusion is within the range of zero and one implies that African countries are partially recovering the excluded segment of the population to access formal financial product.

The coefficient of income is negative and insignificant, which contrary to the economic theory. This implies that increase income decrease access to financial services in African economies, the simple explanation for this is that increase in income mostly is associated with the increase in consumption although there is empirical evidence in a developing country like Nigeria, increase in income most a times is translated into an increase in consumption than servings. This is contrary to the findings of Evans \& Adeoye (2016), Allen, Demirguc-Kunt, Klapper \& Peria (2018), and Soumare, Tchana Kengne (2016), who shows that increase in income increase access to financial services.

The coefficient of ATM access is negative but statistical; this implies that an increase in ATM penetration is associated with financial inclusion in Africa. This is contrary to the prior expectation which contradicts the findings of Bapat \& Biswa (2016) and lqbal and Sami (2017) who shows that access to ATM is associated with high rate of financial inclusion. The negative sign of the coefficient is due to the ATM charges banks normally charge that mostly discourage people to open the account as they view it as a means of exploitation.

The coefficient of MOBILBANK is negative and insignificant; this implies that the availability of mobile banking facilities decreases access to financial services. This has not conformed to the economic theory although it is not significant because of the low rate of acceptability of mobile banking in Africa due to poor internet services, and low awareness on the internet banking in most of the African countries. This is not lined with the findings of Evans \& Adeoye (2016), who show that the availability of mobile banking is a significant determinant of financial inclusion.

The coefficient of CBRANCHES, which is a proxy of bank penetration, is positive but statistically insignificant. This simply implies that physical access to banks increase financial inclusion in Africa where the most segment of the population are excluded due to lack of access to banks, although, the coefficient is insignificant which may be due to the fact that most of the banks are concentrated in the urban centre's neglecting the rural areas. This is in line with the findings of Evans \& Adeoye (2016) and Bapat \& Biswa (2016).

The coefficient of POLITICAL STABILITY is positive and significant, which implies that countries enjoying higher political stability tend to enjoy a high rate of financial inclusion. This conforms to the economic theory.

The coefficient of INTEREST RATE is positive and statistically significant, which implies that the prevailing deposit rate induces financial inclusion, which has conform to the economic theory. Interest rate especially deposit rate play a significant role in financial inclusion by inducing people to save in a formal financial system. This is in tandem with the findings of Evans \& Adeoye (2016), Bapat \& Biswa (2016), and Iqbal and Sami (2017).

The coefficient of INFLATION is positive but insignificant, which implies that an increase in price has a positive impact on financial inclusion. This simply because the increase in prices leads to an increase in profit and demand for formal credit to finance business activities. This is not in tandem with the findings of Bapat \& Biswa (2016), and lqbal \& Sami (2017) who in separate studies show that high inflation discourages people save because of the fear of loss of value of their wealth.

The coefficient of government expenditure is negative and insignificant, meaning that high government expenditure in discourages financial inclusion. This is simply because in Africa increase in government expenditure leads to the crowding out of the private sector in addition to making people lazy. In Africa, also increase in government expenditure is mostly attached with the high rate of corruption where the stolen amounts of money are not kept in the banks but rather in a suck away or hidden in a place rather than taken to a bank. 
Conclusion and recommendations. This study employs a system GMM model to investigate the determinants of financial inclusion in the top ten African countries where principal components analysis was employed to construct a financial inclusion index. We find that mobile banking, commercial bank branches, political stability, interest rate and inflation have a positive impact on financial inclusion in Africa. However, income, access to ATM and government expenditure have a negative impact on financial inclusion. On the basis of the above findings, the study therefore, recommends that the apex banks and policymakers, should design policies that will arrest the problem of unnecessary bank charges, extend the penetration of financial institutions to the rural areas through rural banking scheme and policies, and improve deposit interest rate to induce people to save in the bank. Government expenditure should target critical infrastructure with both short and long-run effect on the welfare of the masses as this will help reduce instability and induce access to finance, in addition to the appropriate monetary and fiscal policy that will increase access to financial inclusion.

\section{References}

Abel, S. Mutandwa. L. \& Le Roux, P. (2018). A Review of the Determinants of Financial Inclusion. International Journal of Economics and Financial Issues, Vol.8(3), 1-8.

Adeyemi. A.A, Pramanik. A. H. (2012). A Measurment Model of the Determinants of Finacial Exclusion Among Mushing MicroEntreprenuers in llorin Nigeria. Journal of /slamic Finance, Vol (1) 1, 030-043.

Ajide, K. B. (2017). Determinants of Financial Inclusion in African countries: Does Institutional Infrustructure Matters? CBN Journal of Applied Statistics, Vol.8(2), 34-45.

Akudugu, M. A. (2013). The Determinants of Financial Inclusion in Western Africa: Insights from Ghana. Research Journal of Finance and Accounting, Vol.4 (8), 23-35.

Allen, F. Demirguc-Kunt, A. Klapper, L. \& Peria. M. S. M. (2018). The Foundation of Financial Inclusion: Understanding Ownership and Use of Accounts. New YORK: World Bank Development Research Group and Private Sector Development.

Anderson, T. W \& Hsiao, C. (1981). Estimation of Dynamic Models with Error Components. American Journal of Statistical Association, Vol. 76, 598-606.

Bapat, D. \& Biswa, N. B. (2018). Determinant of Financial Inclusion of Urban Poor in India: An Empirical Analysis. CESTITO Working Paper, 43-67.

Blundell, R. \& Bond, S. (1998). Initial conditions and Moments Restrictions in Dynamic Panel Data Models. Journal of Econometrics, Vol. 87, 115-143.

Delechat, C. Newiak, M. Xu, R. Yang, F \& Aslan, G. (2018). What is Driving Women Financial Inclusion Across Countries? New York: International Monetary Fund.

Evans, O. \& Adeoye, B (2016). Determinants of Financial Inclusion in Africa: A Dynamic Panel Data Approach. University of Mauritius Reseach Journal, Vol (22)3.

Fairlie, R. W. (2005). An Extension of Blinder-Oaxaca Decomposition Technique to Logit and Probit Models. Journal of Economics and Social Measurement, Vol.30(4), 305-316.

Fawowe, B. (2017). Access to Finance and Firms Performance: Evidence from African Countries. Review of Development Finance, Vol.7(1), 6-17.

Gwalami, H. \& Parkhi, S. (2014). Financial Inclusion Building a Sucess Model in the Indian Context. Procedia-Social and Behavioural Sciences, Vol. 133, 372-378.

Iqbal, B. A. \& Sami, S. (2017). Role of Banks in Financial Inclusion in India. Coutaduriya Administration, Vol.62(3), 1-20.

Kim, D. Yu, J Hassan F. (2018). Financial Inclusion and Economic Growth in IOC countries. Research in International Business and Finance, Vol. 43, 1-14.

Kuri, P. K \& Laha, A. (2017). Determinants of Financial Inclusion: A Study of some selected District of Western Bengal, India. ICSSR Major Research, Department of Economics, University of Western Bengal.

Leach, J. (2004). A Course in Public Economics. New Dhelhi: Cambridge University Press.

Leyshon, A. \& Thrift, N. (1995). Geography of Financialm Exlusion, Financial Abandonmentin Britain Transaction. British Institute of Geogpy Journal, Vol. 20(3), 312-341.

Neaime, S. \& Gaysset, I. (2018). Financial Inclusion and Stability in MENA: EVIDENCE FROM from Poverty and Inequality. Finance Research Letters, Vol.24, 230-237.

Ouma, S. Odongo, T. M. \& Were, M. (2017). Mobile Financial Services and Financial Inclusion: Is it a Bomm for Savings Mobilization? Review of Development Finance, Vol.7(1), 29-35.

Oyelami, L. Saibu, O.M \&Adekunle, B. S. (2017). Determinants of Financial Inclusion in Sub-Saharan African Countries. Conenant Journal of Business and Social Science, Vol.8(2), $19-35$. 
Rajasekaran, N. (2017). Including the Excluded: The Scenerio of Financial Inclusion in India. Journal of Business and Management, Vol.20(2), 64-69.

Rajput, B. (2017). Financial Inclusion and its Determinants: An Empirical Study on the inter State Variasion in India International journal on Arts Managements and Humanities, Vol.6(1), 8-18.

Rao, K. S. \& Baza, A. U. (2017). Barriers to Access to and Usage of Financial Services in Ethopia. Business and Economic Reseach, Vol. 7(1), 139-148.

Sahoo, A. K. (2017). Determinants of Financial Inclusion in Tribal Districts of Odisha: An Empirical Investigation. Social Change, Vol. 47(1), 1-20.

Sharma, A. T. Pradhan, B. B. \& Sahu, N. C. (2013). An Analytical Study of the Relevance of Financial Inclusionfor Developing Nations. Research Inventry, International Journal of Engineering and Science, Vol. (2) 6, 15-20.

Singh, P. Sikdar, S\& Chaturvedi, A. (2017). Determinants of Financial Inclusion Evidence from India. Asian Journal of Research in Banking and FinanceVol.7(12), 67-86.

Soumare, I. Tchana, F. \& Kengne, T. M. (2016). Analysis of the Determinants of Financial Inclusion in Central and Western Africa. Rransnational Corporation Review, 35-48.

Tambunlertchai, K. (2018). Determinants of Barriers to Financial Inclusion in Myanmar: What Determine Access to Financial Services and What Hinders it? The Singapore Economic Review, Vol.3(6), 1-18.

Tita, A. F. \& Aziakpono, M. J. (2017). The Effect of Financial Inclusion on Welfare in Sub-Saharan Africa: Evidence from Disaggregated Data. Johaniburg: National Treasury bof South Africa.

Triki, T. \& Faye, I. (2013). Financial Inclusion in Africa. Tunisia: African Development Bank Group.

Varian, H. R. (2010). Intermediate MicroEconomics, Mordern Approch. New York City: Norton \& Company.

Wale. L. E \& Makina, D. (2017). Account Ownership and Use of Financial Services among some SelectedSub-Saharan African Countries. African Journal of Economic and Business Studies, Vol.8(1), 19-35.

Yakubu, I. Dinye, R \& Idrisu, W. A. (2017). Discriminant Analysis of Demand Side Road Blocks to Financial Inclusion in Northern Ghana. Journal of Mathematical Finance, Vol.7(1), 718-733.

World Bank (2014). Financial Inclusion, Global Financial Development Report. Wasington: World Bank Group.

World Bank (2017) World Bank Development Indicators. http://www.data.worldbank.org.

World Governance Indicators (2017) World Wide Governance Indicators. http://www.worldwidegovernanceindicators.org.

Zins, A. \& Weill, L. (2016). The Determinants of Financial Inclusion in Africa. Review of Development Finance, Vol.6(1), 46-57.

Zuzana, F. \& Weill. L. (2014). Understanding Financial Inclusion in China: Bank of Financial Institutions in Transition Economy. Discussion Journal, 34-54.

I. X. Бакарі, Ph.D, доцент, Технологічний університет імені Адама Мадіббо (Нігерія);

A. Ідді, Державний університет ім. Гомбе (Нігерія);

ю. Ібрагім, Державний університет ім. Гомбе (Нігерія).

Інноваційні детермінанти фінансової інклюзивності топ-десяти країн Африки: GMМ підхід

Фінансова інклюзивність відіграє важливу роль у боротьбі з ключовими проблемами суспільства, а саме: бідність та безробіття, що у свою чергу стримують економічне зростання країн Афррики. У рамках даної статті автори досліджують драйвери фонансової інклюзивності серед десяти країн Африки з точки зору темпів зростання валового внутрішнього продукту. Об'єктом дослідження було обрано десять лідируючих країн Африки, а саме: Ангола, Алжир, Єгипет, Кенія, Лівія, Нігерія, Марокко, Південна Африка, Судан та Туніс. Аналізований період: 2000-2015 роки. 3 метою аналізу панельних даних автори застосовували узагальнений метод моментів (GMM). Даний метод дає можливість вирішити проблеми суб'єктивності, ендогенності та автокореляції. Дані для аналізу було взято з показників світового розвитку (World Development Indicators) та світові індикатори публічного управління (Worldwide Governance Indicators), які визнані найбільш достовірними базами даними, особливо для країн, що розвиваються. Результати дослідження свідчать, що розвиток мобільного банкінгу, розширення мереж банківських філій, політична стабільність, зниження процентних ставок та зменшення рівня інфляціі позитивно впливають на фінансову інклюзивність. На основі вищенаведених результатів дослідження автори виокремлюють наступні детермінанти фінансової інклюзивності для країн Африки: мобільний банкінг, банківська філія, політична стабільність, процентна ставка та рівень інфляції. Враховуючи отримані результати, авторами визначено, що відповідні рішення щодо модернізації фінансової політики повинні прийматись стейкхолдерами з урахуванням ключового положення. забезпечення доступу до ринку фінансових послуг для всіх категорій населення за рахунок низьких процентних ставок. Окрім цього, автори наголошують на необхідності про скасування додаткових банківських комісій та забезпечені проникнення фінансових установ в сільські райони. Фіскальна та монетарна політика повинна спрямовуватися на підвищення добробуту суспільства, особливо населення з низьким рівнем доходу, які переважно не мають доступу до ринку фінансових послуг в Африці.

Ключові слова: зайнятість, фінансова інклюзивність, фіскальна політика, монетарна політика, узагальнений метод моментів.

Manuscript received: 22.09.2018

(c) The author(s) 2018. This article is published with open access at Sumy State University. 